\title{
Rethinking edTPA: \\ The Use of InTASC Principles and Standards
}

\author{
Nai-Cheng Kuo (Corresponding author) \\ Department of Teaching and Leading, Augusta University \\ 2500 Walton Way, Augusta, Georgia 30904, USA \\ E-mail: nkuo@augusta.edu
}

Received: February 21, 2018 Accepted: March 17, 2018 Published: March 19, 2018

doi:10.5296/jei.v4i1.12691ＵRL: https://doi.org/10.5296/jei.v4i1.12691

\begin{abstract}
The Interstate Teacher Assessment and Support Consortium (InTASC) Model Core Teaching Standards and Learning Progressions for Teachers 1.0, developed by the Council of Chief State School Officers (CCSSO, 2013) in the United States, provide a set of expectations for essential knowledge, critical disposition, and performance needed for high-quality teaching. In this article, there are two parts. Part I addresses issues found in a current mandatory policy - edTPA. Part II explores how teacher educators can use the national teacher education standards to create a learning community where the voices of preservice teachers, teacher educators, and school personnel are equally valued.
\end{abstract}

Keywords: InTASC standards, edTPA, Teacher education, Preservice teachers

\section{Introduction}

The Interstate Teacher Assessment and Support Consortium (InTASC) Model Core Teaching Standards and Learning Progressions for Teachers 1.0 are developed by the Council of Chief State School Officers (CCSSO, 2013) in the United States. The InTASC standards and learning progressions provide a set of expectations for essential knowledge, critical disposition, and performances needed for high-quality teaching. These standards allow educators, both inservice and preservice teachers, to show "the increasing complexity and sophistication of teaching practice for each core standard across three developmental levels." (CCSSO, 2013, p. 3). In particular, the learning progressions are to: 1) provide "a robust formative and supportive improvement process to help teachers become more effective," and 2) to articulate "a continuum of growth and higher levels of performance with some specificity before holding practitioners accountable for those levels of performance" (p. 10). The InTASC standards and learning progressions facilitate educators in monitoring their own 
progress as well and identifying professional learning suitable for their teaching context. This paper involves two parts. Part I addresses issues found in a current teacher performance assessment - edTPA. Part II explores how teacher educators can use the national teacher education standards to create a learning community where the voices of preservice teachers, teacher educators, clinical teachers, and school administrators are valued and it has no cost to preservice teachers.

\section{Part One-Issues in the edTPA}

The edTPA is a high-stakes assessment published by Pearson Education Incorporated in partnership with the Stanford Center for Assessment, Learning, and Equity. At present, eighteen states in the nation adopt edTPA. The majority of the states (32 states) use their own state teacher licensure testing and performance assessment. It is stated by the center that the 2014 edTPA is aligned with the 2013 InTASC model core teaching standards (SCALE, 2014). In special education, for example, preservice teachers are required to complete three tasks: planning, instruction, and assessment. This includes three to five lesson plans within the same learning unit, supportive documentation, video clips of teaching, and narrative commentaries on their teaching across planning, instruction, and assessment. To receive a good score, or at least a passing score, preservice teachers need to write all the information into a detailed set of edTPA rubrics (Au, 2013; Ratner \& Kolman, 2016).

To submit their edTPA, preservice teachers have to convert the tasks into appropriate formats and upload them to a designated website. Preservice teachers can use the Pearson ePortfolio system or an integrated edTPA platform provider system such as Chalk \& Wire, Data180, Digication, Edthena, Folio180, Foliotek, Lessoncast, LiveText, PASS-PORT, TaskStream, Tk20, TORSH Talent, or Tumblefeed (edTPA, 2017a). Many universities require their preservice teachers to purchase an integrated edTPA platform provider system. Although Pearson Education Incorporated does not require preservice teachers to use an integrated edTPA platform provider system, many universities require preservice teachers to pass internal edTPA rubrics developed by the universities. To use the integrated edTPA platform provider system, preservice teachers are required to sign an agreement form for their university faculty to view, evaluate, and/or use their edTPA materials for training purposes. If preservice teachers' edTPA portfolios do not pass the internal edTPA rubrics developed by the universities, they will be discouraged from submitting their edTPA portfolios to the Pearson ePortfolio system.

There are fifteen rubrics, five for each of the tasks. Scorers are hired by Pearson Education Incorporated and for scoring edTPA portfolios. Pearson Education Incorporated will send universities reports indicating their preservice teachers' scores. No written feedback or suggestions for improvement are provided to preservice teachers or universities - only numbers. Parents must waive privacy rights and permit videotaping their children if they agree to help preservice teachers with edTPA. University faculty are permitted to use former preservice teachers' completed edTPA for training purposes (edTPA, 2015). If preservice teachers fail edTPA, they are not allowed to make changes to their previous materials. They need to submit new edTPA materials for scoring (edTPA, 2017b). Currently, retaking one task 
is $\$ 100$, retaking two tasks is $\$ 200$, and retaking three tasks is $\$ 300$. Pearson Education Incorporated accepts edTPA portfolio submissions eleven months per year (except January).

\subsection{A Mirror of No Child Left Act (NCLB)}

The edTPA, like NCLB, punishes institutions for their learners' failure based on grades. For example, "the New York State Department of Education (NYSED) has recommended that if fewer than $80 \%$ of a program's candidates pass the edTPA, the teacher preparation program must submit a 'professional development plan' to the state" (O'Brien \& Robb, 2017, p. 4). Like NCLB, to maintain a good standardized assessment passing rate, all kinds of inappropriate practices begin to appear in higher education teacher preparation programs. For instance, regardless of the high risk of revealing the identities of both former preservice teachers and their target learners, the prior meticulously-detailed edTPA materials are used in university classes for training purposes. Moreover, to avoid risk to the institution's edTPA passing rate, universities become reluctant to place their preservice teachers in difficult schools with less support or classes that have too many challenging students (Chiu, 2014). Schools which do not buy into the edTPA or do not support preservice teachers in completing the edTPA portfolio will no longer receive preservice teachers from universities. Due to the fact that the edTPA only provides numerical feedback and the scorers "bring their particular backgrounds and teaching experiences that are difficult to completely separate from the evaluation process" (Othman, Robinson, \& Molfenter, 2017, p. 4), it is unclear how much students' scores are affected by the edTPA scorers' backgrounds and experiences.

$\mathrm{Au}$ (2013) argues that the edTPA is a misuse of the thoughtfully-developed InTASC standards and learning progressions because it turns these standards into a high-stakes, standardized test. The initial value of the InTASC standards and learning progressions of emphasizing formative and useful feedback has now been replaced by a one-time summative assessment. A teacher educator in New York commented, "the edTPA moves teaching and teacher education in the wrong direction and was preventing candidates from engaging in important learning during their capstone student teaching experience" (Ratner \& Kolman, 2016, p. 12). A former student of our institution (who has passed edTPA and is now a formal teacher) commented on the edTPA and said: "The edTPA does not tell us what specifically made us get that score! Just the number! The number does not give us information on ways to improve our instruction." Bartlett, Otis-Wilborn, and Peters's (2017) study further shows that teacher educators in three institution of higher education that prepared special educators, two in the Midwest and one in the Northeast, felt hard-pressed to find ways to support preservice teachers who were not successful on edTPA just based on the number. Overall, the numerical feedback from edTPA gives very little information about how preservice teachers should further improve.

\subsection{School Administrators' and Preservice Teachers' Challenges}

The inconsistency about edTPA implementation, including passing scores and resources, has caused confusion and challenges to the field. In a qualitative study done by Bartlett, Otis-Wilborn, and Peters (2017), school administrators in urban schools who are already facing a great shortage of special education teachers commented on edTPA: 
Are you kidding? We're gonna have somebody on their second year who I finally got hired in the state that has an incredible alarming shortage of special educators. You're gonna tell me you're gonna test somebody in their second year, they're not gonna pass and then they're gonna skedaddle from teaching...you think I'm gonna tell them to make time to do this as a teacher in my school? No way! (p. 10)

In addition, retaking edTPA also causes undue stress to preservice teachers because they need to enroll in a course and pay tuition and fees to maintain their student status. A professor commented on edTPA and said:

You likely enroll in another credit of student teaching or at least have to pay to be placed somewhere to possibly re-do the edTPA. And the burden shifts from us to students which is interesting. If you have a student that struggles in the first place to pass the edTPA and, then, you don't provide them with the same amount of support you did when they're going through, the chance of them being able to pass the retake is possibly less than it was the first time they did it, right? (p. 7)

To prepare preservice teachers for writing edTPA reflective narratives, some universities purchase edTPA preparation materials like ATLAS teaching videos and books, which all add to preservice teachers' tuition and fees. Furthermore, Greenblatt and O'Hara (2015) argue that "the challenges of the edTPA are exacerbated in schools in low-income communities where our k-12 students often are not scoring well on standardized tests" (p. 59). How can preservice teachers be held accountable for their performance on the edTPA if schools lack the conditions to make it possible for them to be successful? The mandatory nature of the edTPA may not cause any big difference in schools that are already well-funded and have rich resources as well as students who are from upper-class families and can afford additional tuition and fees. However, it does more harm than good to schools, which are already facing a great shortage of personnel and resources, as well as students who already have mounting debt to earn their college degree.

\subsection{Educators' Dual Roles}

Preparing preservice teachers based on national teacher education standards is university faculty's duty and responsibility. If teacher leaders are in partnership with university teacher education programs and they receive stipends from universities to supervise preservice teachers during student teaching, preparing preservice teachers based on these standards is also their duty and responsibility. However, some university faculty members and teacher leaders are concurrently employed by Pearson Education Incorporated to serve as edTPA national scorers. According to edTPA (2015), "overall, approximately 50 percent of scorers hired are faculty/supervisors and 50 percent are teacher leaders" (p. 1). By serving as edTPA national scorers, they earn money from each edTPA portfolio they grade. University faculty who are edTPA national scorers employed by Pearson Education Incorporated advocate the use of the edTPA in universities regardless of their students' financial burden. Despite the fact that faculty members' dual roles and practices are questionable, universities still want to hire faculty who are edTPA national scorers, so they can ensure that their preservice teachers get prepared by those who are directly trained by Pearson Education Incorporated. Universities 
now become "test-preparation" institutions. When more and more university faculty and teacher leaders want to become edTPA national scorers and use their regular work time to work on externally paid jobs, it does not provide a good role model to future educators.

\subsection{Artificial Teaching Environment for Cultivating Short-Lived Skills}

Once student teaching placement is decided, university faculty members, clinical teachers, and school administrators have to work together to identify "ideal" target learners and classes for their preservice teachers to complete the edTPA. Such settings are often artificial and are contrary to the real-classroom practices. For instance, professors from the University of Wisconsin and the Wisconsin Department of Public Instruction argue that in the field of special education:

The teacher candidates are expected to teach a group of students with one focus learner. Regardless of school and district-level inclusion policies and practices, the edTPA requirement that a special education candidate select one focus learner is not aligned with the desired learning outcome of the student teaching placement for the candidate. (Othman, Robinson, \& Molfenter, 2017, p. 5)

No public school can afford to hire one special education teacher to focus only on one learner. The teacher must equally focus on all learners in a group. To help candidates pass the edTPA, schools are pushed to create a platform for preservice teachers in spite of the reality. Not just in the field of special education, similar problems are also found in the field of English as a secondary language. Chiu (2014) states, "the world within the various edTPA tasks is unrealistic, and the task demands do not take into consideration the real-life demands of teaching in a public school classroom" (p. 29). Preservice teachers are reluctant to be placed in difficult settings with challenging students (Chiu, 2014). Furthermore, schools are required to excuse preservice teachers for missing their practice during student teaching to attend edTPA seminars like writing boot camps. On average, the written reflections are close to 30 single-spaced pages plus detailed lesson plans ( $\mathrm{Au}, 2013$; Ratner \& Kolman, 2016). One of our clinical teachers commented on edTPA and said, "it is impossible and unrealistic that teachers can write such a lengthy lesson plan (three to four single-spaced pages per lesson) for each 50-minute class every day." It is found that the edTPA has created financial, time, and stress burdens for preservice teachers, and has interfered with their teaching responsibilities (Burns, Henry, \& Lindauer, 2015; Greenblatt, 2016; O’Brien \& Robb, 2017).

It is concerning when preservice teachers mainly focus their time and energy of student teaching on crafting three to five potentially high-scoring lesson plans, teaching videos, assessments, and commentaries for the edTPA. The other lesson plans, activities, and materials that will not be submitted for the edTPA are done with lower quality due to the exhaustion of their time and energy. This shows that the edTPA only cultivate preservice teachers' short-lived skills. Preservice teachers do not continue or transfer the skills that they use for the edTPA lessons to non-edTPA lessons. With preservice teachers' time and energy shifting to prepare their edTPA portfolios, it will in turns affect students, especially those who are not the target learners of these preservice teachers (Othman, Robinson, \& Molfenter, 2017). 


\subsection{A Means to Add Test-Preparation Avails}

The negative impact of edTPA does not stop in school practices. It also affect higher education. Teacher educators understand that their preservice teachers must pass edTPA in order to be certified teachers. Thus, they have to change course contents and fieldwork experiences to prepare preservice teachers for edTPA (Othman, Robinson, \& Molfenter, 2017). Bartlett, Otis-Wilborn, and Peters's (2017) study shows that "across institutions, teacher educators engaged in curriculum mapping activities that purposefully matched edTPA content and tasks with courses and teaching experiences" (p. 5). O'Brien and Robb (2017) state, "the edTPA is driving virtually all coursework and assessment throughout our program now" (p. 6). Because passing the edTPA is all that matters, the fifteen edTPA rubrics have become the core value of teacher education. Comparing with knowing the purpose and value of education, preservice teachers now care more about how to best capture their target learners on video and how to answer edTPA questions to receive a high score on the rubrics (Chiu, 2014). Because the expertise of university faculty is devalued and teacher education programs become test preparation programs, it will soon affect how future educators view a higher education. Because non-traditional teacher preparation programs are also required to prepare candidates for edTPA, the edTPA policy is likely to encourage the development of companies which provide short- and fast-pathways for teacher preparation and aim at a high passing rate of high-stake exams (O’Brien \& Robb, 2017).

\subsection{Lack of a Meaningful Mentorship during Student Teaching}

Many practices in preparing preservice teachers for the edTPA are contrary to the expectations of the InTASC standards and learning progressions. In this way, how can we expect that teachers will practice these standards when they become teachers? For example, the InTASC standards and learning progressions encourage a mentorship to be the center of creating a collaborative learning culture. However, the edTPA makes it clear that teacher educators are not allowed to provide critical comments on preservice teachers' edTPA materials (on which preservice teachers spend the majority of their time and energy during their student teaching). Teacher educators are not allowed to show their preservice teachers how they will teach differently in the same context or guide them to think critically on their edTPA lessons. With all the restrictions, there is not much meaningful mentorship between university faculty and preservice teachers in the final semester of the program.

The InTASC standards and learning progressions are supposed to encourage preservice teachers to be active learners in the process of pursuing their teaching certification. These standards and progressions provide a vehicle for every stakeholder to work jointly and go beyond any individual becoming the only target to be changed. However, the edTPA discourages the development of a shared sense of responsibility for improving education. In the edTPA, only the voice of scorers employed by Pearson Education Incorporated matters. These scorers hold the highest authority and can deny a candidate's teaching license on the spot. Moreover, preservice teachers need better reading, writing, and technological skills than pedagogical skills to pass the edTPA, (Greenblatt \& O'Hara, 2015). Such an assessment promotes preservice teachers to write skillfully (or even lie) to pass edTPA. Not only teacher 
educators, clinical teachers, and school administrators but also preservice teachers struggle with how making teaching conform to the edTPA is relevant to the real-classroom practices. While research-valid approaches are encouraged to be used in the classroom, the mandatory policy of requiring teacher educators and preservice teachers to abide by edTPA rubrics is not based on any rigorous empirical studies that show its impact on students' learning.

\section{Part Two-An Alternative Way to Use the InTASC Standards}

One responsibility of teacher educators at universities is to use meaningful and cost-effective assessments to evaluate preservice teachers' essential knowledge, critical dispositions, and performance during fieldwork and the student teaching semester. Appendix 1 shows an example about how teacher educators can flexibly use the national standards to maximize preservice teachers' learning opportunities while keeping the spirit of the original InTASC standards. Learning from the six issues found in the edTPA, this alternative way of using the InTASC standards aims to:

> Promote shared responsibility for preservice teachers' performance

$>$ Advocate the use of national standards at no extra cost to preservice teachers

> Uphold the integrity of teacher educators' profession

> Broaden the curriculum, rather than narrowing, to prepare preservice teachers for real-world classrooms

> Hold higher education teacher preparation programs accountable for preservice teachers' progression of knowledge, dispositions, and performance

\section{$>$ Encourage a meaningful mentorship during the student teaching semester}

This alternative assessment based on the InTASC standards opens a dialogue for preservice teachers, university faculty, clinical teachers, and school administrators to discuss, refine, and decide how to use the standards in the real-world classroom practice. All personnel (i.e., preservice teachers, university faculty, and school personnel) are welcome to share their input and discuss the use of the assessment instrument. In this alternative assessment, the standards serve as the impetus to engage all personnel in debate and dialogues about how to teach professionally and ethically. These standards are not to be used as rubrics to fail preservice teachers or to punish institutions. Instead, they provide information for all personnel to consider, question, and examine the common issues that they are facing in order to share the responsibility for professional growth. Because the assessment results are used to celebrate strengths and identify areas for all personnel's growth and improvement, it encourages educators to view the use of standards positively and to develop a meaningful mentorship during fieldwork and the student teaching semester.

\subsection{Suggested Steps about Using the InTASC Standards}

Teacher educators can easily modify the InTASC standards and use them as one of the assessments to evaluate preservice teachers' performance during fieldwork or student 
teaching. The following suggested steps assist preservice teachers, university faculty, and school personnel in creating an alternative assessment based on the InTASC standards.

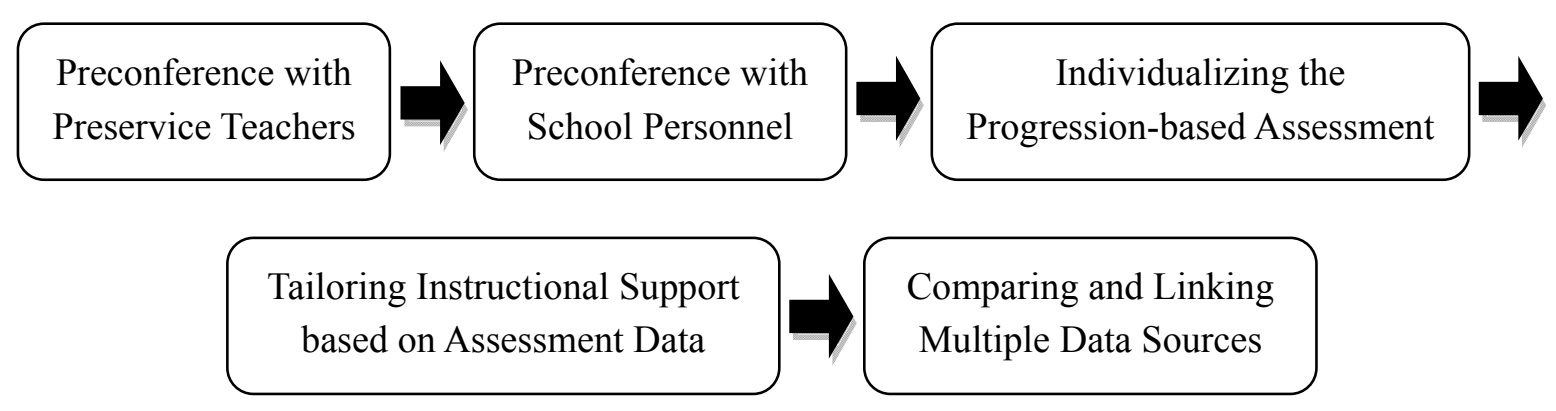

Figure 1. Suggested steps about using the InTASC standards

Prior to fieldwork or student teaching, university faculty schedule a meeting with their supervised preservice teachers to discuss the use of this alternative assessment. University faculty should inform preservice teachers that the indicators under each InTASC standard only serve as foundational points. These existing indicators can be (and should be) revised based on the respective cultural context of the school where the preservice teacher is placed. For example, integrative teaching skills may be emphasized in a Science, Technology, Engineering, Arts, and Mathematics (STEAM) school more than in a non-STEAM school.

University faculty will then meet with the teacher candidate's clinical teacher and/or school administrator to discuss the use of this alternative assessment to evaluate the teacher candidate's performance. Changes in the indicators of the InTASC standards should be made as needed.

After meeting with preservice teachers, clinical teachers, and school administrators, university faculty will revise and finalize this alternative assessment. Taking into account contextual factors, one teacher candidate's assessment may be slightly different from the other teacher candidate's assessment. Furthermore, with a little help from university IT staff, teacher educators can make this alternative assessment (see Appendix 1) an editable PDF so that evaluators could type digitally in the final column. It will be even user-friendly to make the checkboxes clickable and code it so that the number of boxes will auto-fill. Overall, this alternative assessment allows both quantitative and qualitative feedback from all personnel to inform instructional support.

How often all personnel should communicate their feedback is decided based on their discussions. Take student teaching as an example, the feedback can be provided in the middle and at the end of the semester or as many times as needed. The evaluation data are to be used to inform ongoing instructional support to preservice teachers.

In addition to this alternative assessment, university faculty should consider multiple assessment data, both formal assessments (e.g., state teacher certification examinations) and informal assessments (e.g., feedback from students, parents, colleagues, and course 
instructors of the preservice teacher). Based on preservice teachers' overall performance across different data sources, university faculty can guide them for future professional development.

\section{Conclusion}

It is easy for university faculty not to do their job and simply ask preservice teachers to pay extra money to be evaluated by the outside profession. It is also attempting for university faculty to find a way to make extra money alongside their regular work hours. A policy like the mandate of the edTPA can cripple the development of a genuine education by encouraging people to work simply "by the book" (i.e., Just follow the edTPA handbook to prepare the teacher!). Education must empower and cultivate individuals to reject and resist an inappropriate policy in all its forms. After all, when a policy benefits interest groups more than the people it intends to serve, it will bring the whole system to halt. If following the national teacher education standards to prepare preservice teachers is university faculty's duty and responsibility, we should ask: Do teacher educators really need a corporation to help them evaluate their teaching? If so, why is it at preservice teachers' expense to "prove" that their universities are using the InTASC standards to prepare them?

\section{References}

$\mathrm{Au}, \mathrm{W}$. (2013). What is a nice test like you doing in a place like this? The edTPA and corporate education 'reform'. Rethinking Schools, 24(4), 22-27.

Bartlett, M., Otis-Wilborn, A., \& Peters, L. (2017). Bending or breaking: Appropriating edTPA policy in special education teacher education. Teacher Education and Special Education, 00(0), 1-12. https://doi.org/10.1177/0888406417720188

Burns, B. A., Henry, J. J., \& Lindauer, J. R. (2015). Working together to foster candidate success on the edTPA. Journal of Inquiry \& Action in Education, 6(2), 18-37.

Chiu, S. (2014). edTPA: An assessment that reduces the quality of teacher education. Teachers College, Columbia University, Working Papers in TESOL \& Applied Linguistics, 14(1), 28-30.

Council of Chief State School Officers. (2013). Interstate teacher assessment and support consortium (InTASC) model core teaching standards and learning progressions for teachers 1.0: A resource for ongoing teacher development. Washington, DC: Author.

edTPA. (2015). edTPA myths and facts. Pearson Education Incorporated. Retrieved from https://www.uwgb.edu/UWGBCMS/media/Academics/edtpa-myth-busters.pdf

edTPA. (2017a). Your authorization key. Pearson Education Incorporated. Retrieved from https://www.edtpa.com/PageView.aspx?f=GEN_AuthorizationKey.html

edTPA. (2017b). edTPA retake decision-making and support guidelines for programs and faculty. Pearson Education Incorporated. Retrieved from http://www.edtpa.com/content/docs/ edtparetakeguidelines.pdf 


\section{Macrothink}

Journal of Educational Issues

ISSN 2377-2263

2018, Vol. 4, No. 1

Greenblatt, D. (2016). The consequences of edTPA. Educational Leadership, 73(8), 51-54.

Greenblatt, D., \& O'Hara, K. E. (2015). Buyer beware: Lessons learned from edTPA implementation in New York State. Thought \& Action, 42, 57-67.

O'Brien, L., \& Robb, S. N. (2017). Rage against the machine: Teacher educators try to throw a wrench in the (edTPA) works. Critical Education, 8(7), 1-24.

Othman, L., Robinson, R., \& Molfenter, N. F. (2017). Emerging issues with consequential use of the edTPA: Overall and through a special education Lens. Teacher Education and Special Education, 40(4), 269-277. https://doi.org/10.1177/0888406417718251

Ratner, A. R., \& Kolman, J. S. (2016). Breakers, benders, and obeyers: Inquiring into teacher educators' mediation of edTPA. Education Policy Analysis Archives, 24(35), 1-29. https://doi.org/10.14507/Epaa.24.2112

SCALE. (2014). edTPA (2014) crosswalk: Interstate teacher support and assessment consortium (InTASC) model core teaching standards (2013). Stanford Center for Assessment, Learning, and Equity (SCALE). 


\section{Appendix}

\section{Appendix 1. An Example of Using the InTASC Standards Alternatively}

\section{Standard 1: Learner Development}

The teacher uses understanding of how learners grow and develop (in cognitive, linguistic, social, emotional, and physical areas) to design and implement developmentally appropriate and challenging learning experiences.

\begin{tabular}{|c|c|c|c|}
\hline $\begin{array}{l}\text { 1: Essential } \\
\text { Respects students for who they } \\
\text { are }\end{array}$ & $\begin{array}{l}\text { 2: Professional } \\
\text { Supports and challenges students to } \\
\text { uncover potential }\end{array}$ & $\begin{array}{l}\text { 3: Exemplary } \\
\text { Grows alongside students }\end{array}$ & $\begin{array}{l}\text { Evaluated by: } \\
\text { Preserve teacher } \\
\text { University faculty } \\
\text { School personnel }\end{array}$ \\
\hline $\begin{array}{l}\square \quad \text { Drawing on her/his } \\
\text { understanding of child and } \\
\text { adolescent development, the } \\
\text { teacher observes learners, } \\
\text { noting changes and patterns in } \\
\text { learners across areas of } \\
\text { development, and seeks } \\
\text { resources, including from } \\
\text { families and colleagues, to } \\
\text { adjust teaching. } \\
\square \quad \text { The teacher actively } \\
\text { seeks out information about } \\
\text { learner interests in order to } \\
\text { engage learners in } \\
\text { developmentally appropriate } \\
\text { learning experiences. } \\
\square \quad \text { The teacher engages } \\
\text { learners in a variety of } \\
\text { learning experiences to } \\
\text { capitalize on strengths and } \\
\text { build areas of development that } \\
\text { are weaker. }\end{array}$ & 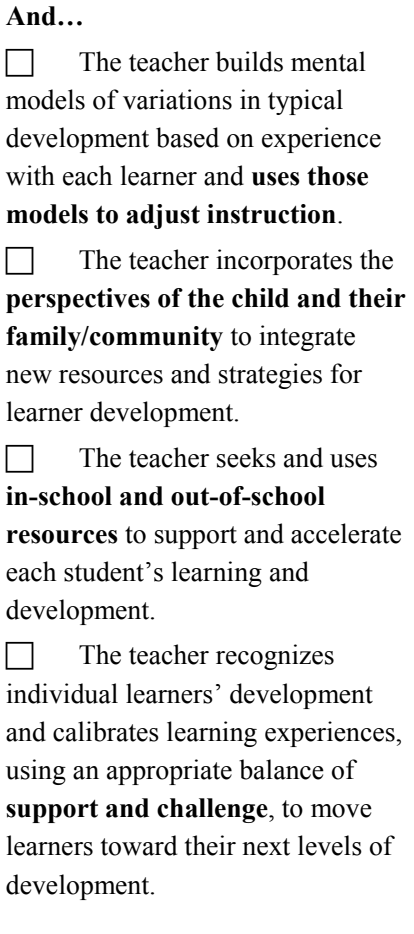 & 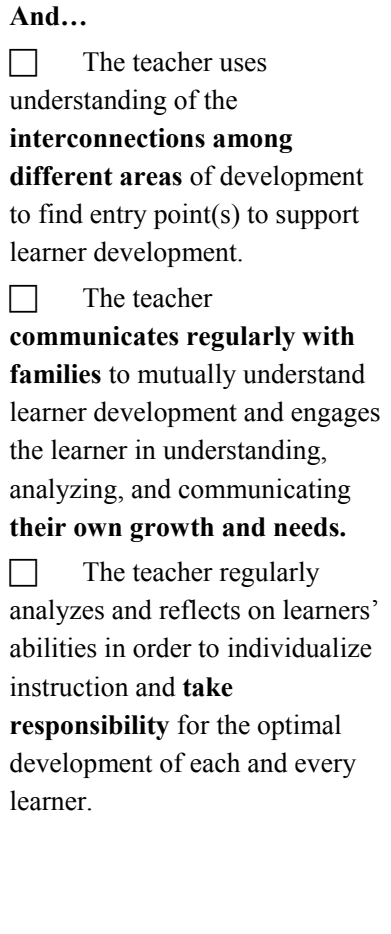 & $\begin{array}{l}\text { Descriptive feedback } \\
\text { about needed support } \\
\text { (e.g., training, task } \\
\text { clarification, } \\
\text { resources/materials, } \\
\text { performance } \\
\text { consequence, etc.) }\end{array}$ \\
\hline
\end{tabular}

Note. Modified from the InTASC Model Core Teaching Standards and Learning Progressions for Teachers 1.0 (2013, Page 18). 


\section{Standards 2: Learning Differences}

The teacher uses understanding of learners' commonalities and individual differences within and across diverse communities to design inclusive learning experiences that enable each learner to meet high standards.

\begin{tabular}{|c|c|c|c|}
\hline $\begin{array}{l}\text { 1: Essential } \\
\text { Abides by legal requirements of } \\
\text { accommodation }\end{array}$ & $\begin{array}{l}\text { 2: Professional } \\
\text { Continues to deepen } \\
\text { understanding and adapt } \\
\text { instruction }\end{array}$ & $\begin{array}{l}\text { 3: Exemplary } \\
\text { Challenges students, provides } \\
\text { support, and cultivates respect for } \\
\text { diverse culture }\end{array}$ & $\begin{array}{l}\text { Evaluated by: } \\
\text { Preserve teacher } \\
\text { University faculty } \\
\text { School personnel }\end{array}$ \\
\hline $\begin{array}{l}\square \text { Drawing upon her/his } \\
\text { understanding of second } \\
\text { language acquisition, exceptional } \\
\text { needs, and learners' background } \\
\text { knowledge, the teacher observes } \\
\text { individual and groups of learners } \\
\text { to identify specific needs and } \\
\text { responds with individualized } \\
\text { support. } \\
\square \quad \text { Recognizing how diverse } \\
\text { learners process information and } \\
\text { develop skills, the teacher } \\
\text { incorporates multiple } \\
\text { approaches to learning. } \\
\square \quad \text { Using information on } \\
\text { learners' language proficiency } \\
\text { levels, the teacher incorporates } \\
\text { tools of language development } \\
\text { into planning and instruction to } \\
\text { make content and academic } \\
\text { language accessible to } \\
\text { linguistically diverse learners. } \\
\square \quad \text { The teacher includes } \\
\text { multiple perspectives in the } \\
\text { presentation and discussion of } \\
\text { content that include each } \\
\text { learner's personal, family, } \\
\text { community, and cultural } \\
\text { experiences and norms. } \\
\square \quad \text { The teacher applies } \\
\text { interventions, modifications, and } \\
\text { accommodations based on IEPs, } \\
\text { IFSPs, } 504 \text { s and other legal } \\
\text { requirements, seeking advice } \\
\text { and support from specialized } \\
\text { support staff and families. } \\
\square \quad \text { The teacher follows a } \\
\text { process, designated by a school } \\
\text { or district, for identifying and } \\
\text { addressing learner needs and } \\
\text { documents learner progress. }\end{array}$ & 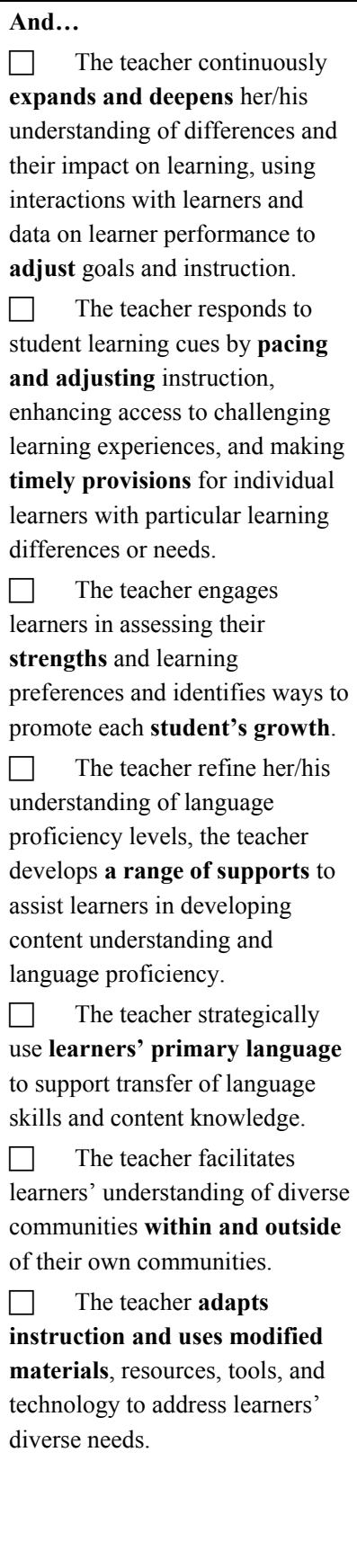 & 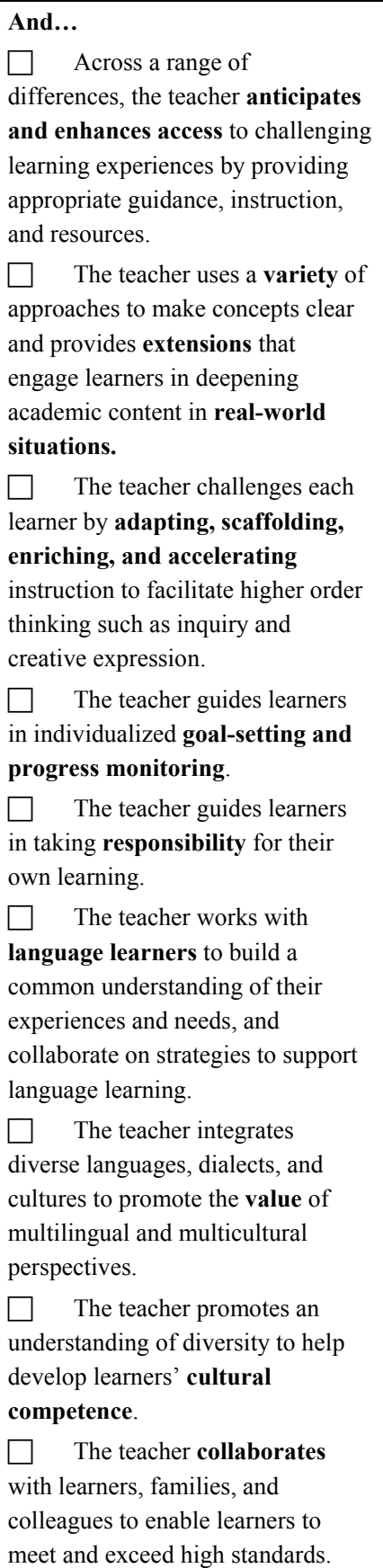 & $\begin{array}{l}\text { Progress } \\
\text { monitoring: } \\
\text { \# of boxes } \\
\text { checked/total \# of } \\
\text { boxes section }\end{array}$ \\
\hline
\end{tabular}

Note. Modified from the InTASC Model Core Teaching Standards and Learning Progressions for Teachers 1.0 (2013, Page 19). 


\section{Standard 3: Learning Environment}

The teacher collaborates with others to build a positive learning climate marked by respect, rigor, and responsibility and manages that learning environment to engage learners actively.

\begin{tabular}{|c|c|c|c|}
\hline $\begin{array}{l}\text { 1: Essential } \\
\text { Conveys expectations for a } \\
\text { respectful learning environment }\end{array}$ & $\begin{array}{l}\text { 2: Professional } \\
\text { Models respectful interactions }\end{array}$ & $\begin{array}{l}\text { 3: Exemplary } \\
\text { Collaborates with others to } \\
\text { promote respectful interactions }\end{array}$ & $\begin{array}{l}\text { Evaluated by: } \\
\text { Preserve teacher } \\
\text { University faculty } \\
\text { School personnel }\end{array}$ \\
\hline 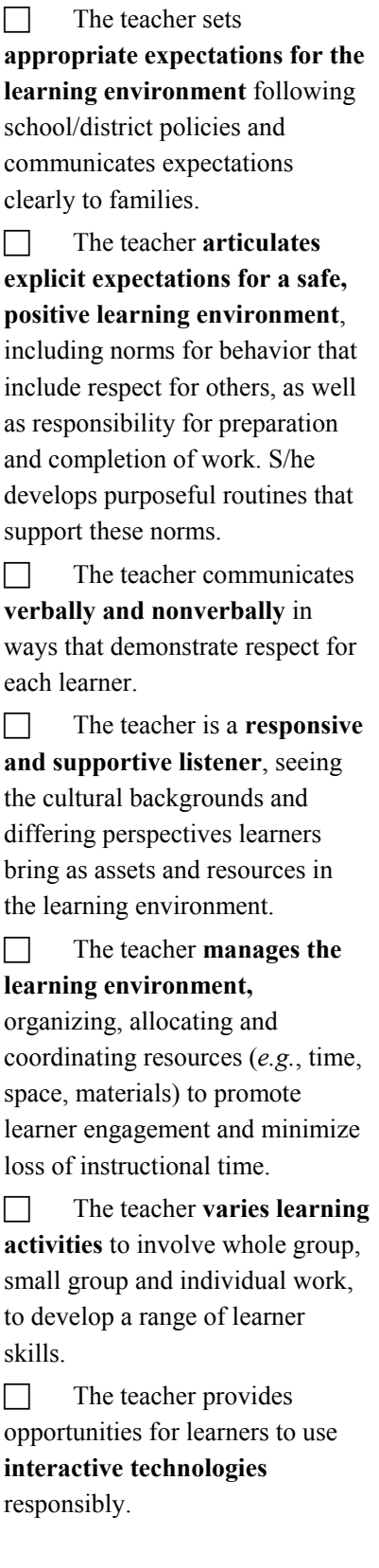 & 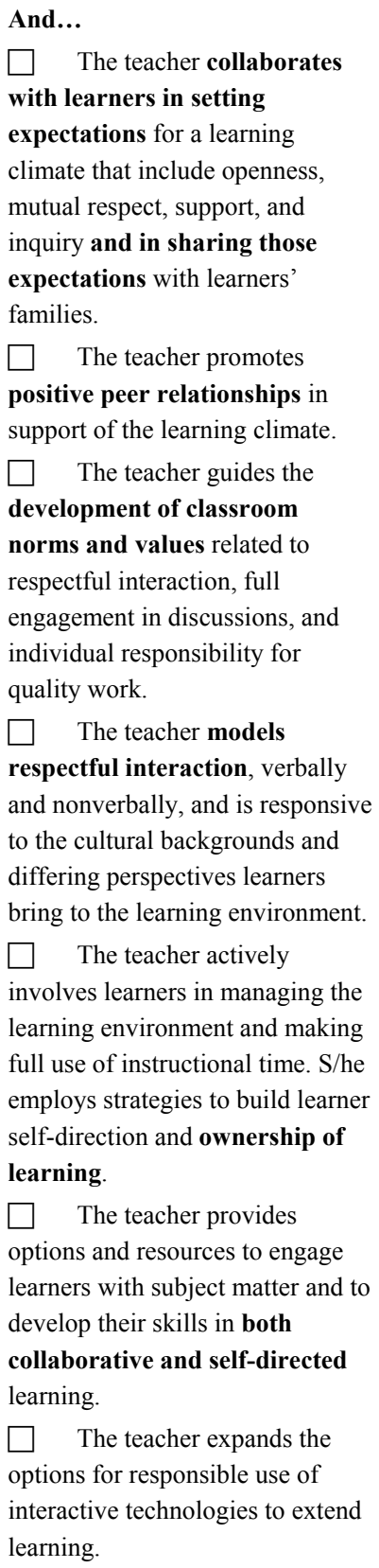 & 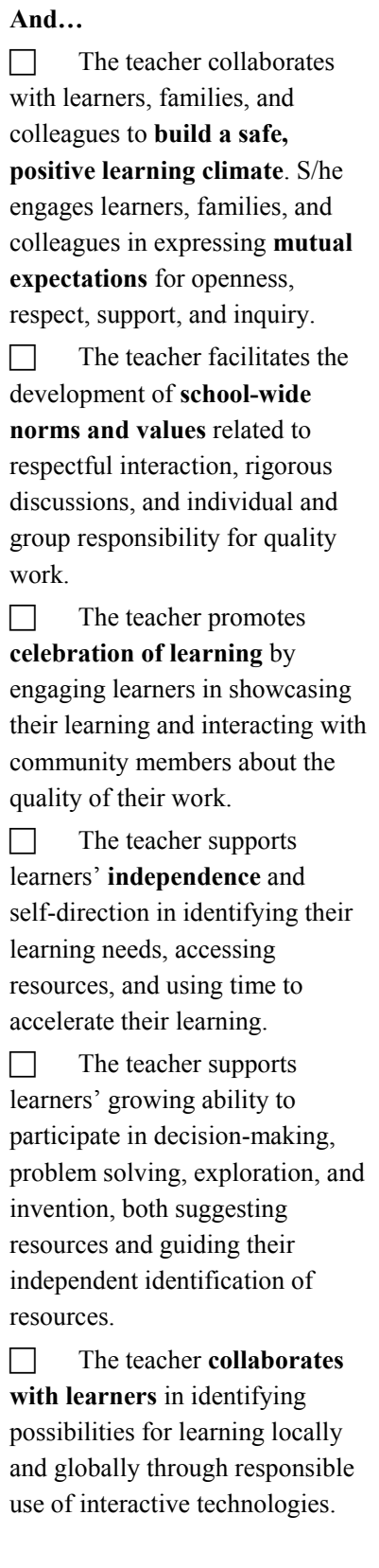 & $\begin{array}{l}\text { Progress } \\
\text { monitoring: } \\
\text { \# of boxes } \\
\text { checked/total \# of } \\
\text { boxes section }\end{array}$ \\
\hline
\end{tabular}

Note. Modified from the InTASC Model Core Teaching Standards and Learning Progressions for Teachers 1.0 (2013, Pages 22-23). 


\section{Standard 4: Content Knowledge}

The teacher understands the central concepts, tools of inquiry, and structures of the discipline(s). She/he creates learning experiences that make the discipline accessible and meaningful for learners to assure mastery of the content.

\begin{tabular}{|c|c|c|c|}
\hline $\begin{array}{l}\text { 1: Essential } \\
\text { Demonstrates accuracy and uses a } \\
\text { variety of instructional methods }\end{array}$ & $\begin{array}{l}\text { 2: Professional } \\
\text { Expands and deepens knowledge } \\
\text { and helps students connect to } \\
\text { real-life application }\end{array}$ & $\begin{array}{l}\text { 3: Exemplary } \\
\text { Expands teaching repertoire } \\
\text { through collaboration, and } \\
\text { promotes critical thinking }\end{array}$ & $\begin{array}{l}\text { Evaluated by: } \\
\text { Preserve teacher } \\
\text { University faculty } \\
\text { School personnel }\end{array}$ \\
\hline $\begin{array}{l}\text { The teacher accurately and } \\
\text { effectively communicates concepts, } \\
\text { processes and knowledge in the } \\
\text { discipline, and her/his use of } \\
\text { vocabulary and academic language } \\
\text { is clear, correct and appropriate } \\
\text { for learners. } \\
\square \quad \text { The teacher draws upon } \\
\text { her/his initial knowledge of } \\
\text { common misconceptions in the } \\
\text { content area, uses available } \\
\text { resources to address them, and } \\
\text { consults with colleagues on how to } \\
\text { anticipate learners' needs for } \\
\text { explanations and experiences that } \\
\text { create accurate understanding in } \\
\text { the content area. } \\
\square \quad \text { The teacher uses multiple } \\
\text { representations and explanations } \\
\text { that capture key ideas in the } \\
\text { discipline, guide learners through } \\
\text { learning progressions, and promote } \\
\text { each learner's achievement of } \\
\text { standards. } \\
\square \quad \text { The teacher engages learners } \\
\text { in applying methods of inquiry } \\
\text { used in the discipline. } \\
\square \quad \text { The teacher links new } \\
\text { concepts to familiar concepts and } \\
\text { helps learners see them in } \\
\text { connection to their prior } \\
\text { experiences. } \\
\square \quad \text { The teacher models and } \\
\text { provides opportunities for } \\
\text { learners to understand academic } \\
\text { language and to use vocabulary to } \\
\text { engage in and express content } \\
\text { learning. } \\
\square \quad \text { The teacher consults with } \\
\text { other educators to make academic } \\
\text { language accessible to learners } \\
\text { with different backgrounds. }\end{array}$ & 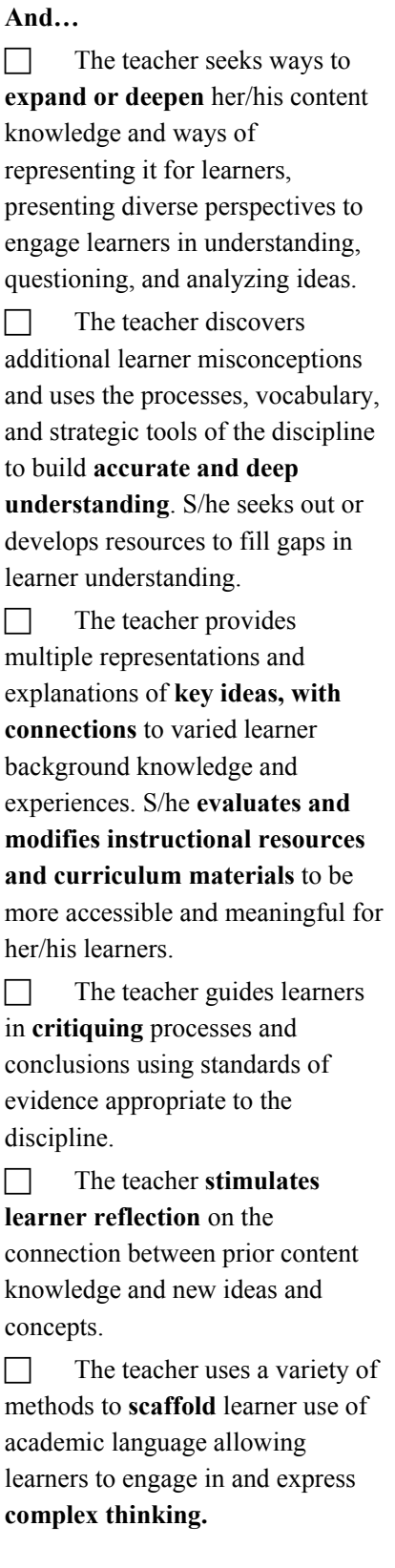 & 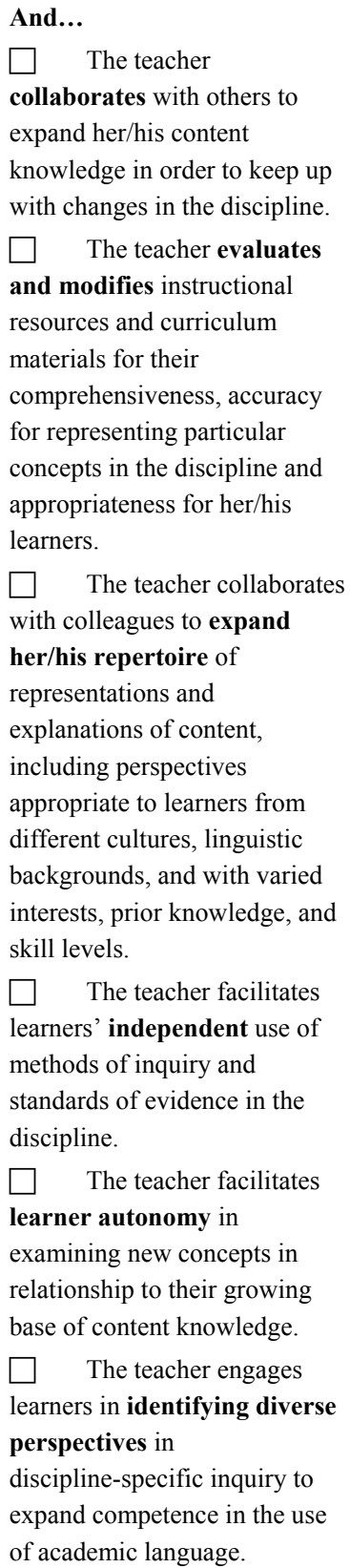 & $\begin{array}{l}\text { Progress } \\
\text { monitoring: } \\
\text { \# of boxes } \\
\text { checked/total \# of } \\
\text { boxes section }\end{array}$ \\
\hline
\end{tabular}

Note. Modified from the InTASC Model Core Teaching Standards and Learning Progressions for Teachers 1.0 (2013, Pages 25-26). 


\section{Standard 5: Application of Content}

The teacher connects concepts, perspectives from varied disciplines, and interdisciplinary themes to real world problems and issues. She/he engages learners in critical thinking, creativity, collaboration, and communication to address authentic local and global issues.

\begin{tabular}{|c|c|c|c|}
\hline $\begin{array}{l}\text { 1: Essential } \\
\text { Cultivates integrative, critical } \\
\text { thinking, and effective } \\
\text { communication }\end{array}$ & $\begin{array}{l}\text { 2: Professional } \\
\text { Collaborates with others across } \\
\text { disciplines to promote inquiry and } \\
\text { communication. }\end{array}$ & $\begin{array}{l}\text { 3: Exemplary } \\
\text { Applies knowledge to plan and } \\
\text { carry out research to resolve } \\
\text { real-life problems }\end{array}$ & $\begin{array}{l}\text { Evaluated by: } \\
\text { Preserve teacher } \\
\text { University faculty } \\
\text { School personnel }\end{array}$ \\
\hline $\begin{array}{l}\text { The teacher helps learners } \\
\text { see relationships across } \\
\text { disciplines by making connections } \\
\text { between curriculum materials in a } \\
\text { content area and related } \\
\text { perspectives from another content } \\
\text { area or areas. } \\
\square \quad \text { The teacher engages } \\
\text { learners in applying content } \\
\text { knowledge and skills in authentic } \\
\text { contexts. } \\
\square \quad \text { The teacher engages } \\
\text { learners in learning and applying } \\
\text { the critical thinking skills used in } \\
\text { the content area(s). S/he } \\
\text { introduces them to the kinds of } \\
\text { problems or issues addressed by } \\
\text { the content area(s) as well as the } \\
\text { local/global contexts for those } \\
\text { issues. } \\
\square \quad \text { The teacher engages } \\
\text { learners in developing literacy } \\
\text { and communication skills that } \\
\text { support learning in the content } \\
\text { area(s). S/he helps them recognize } \\
\text { the disciplinary expectations for } \\
\text { reading different types of text and } \\
\text { for writing in specific contexts. } \\
\square \quad \text { The teacher provides } \\
\text { opportunities for learners to show } \\
\text { their understanding in unique } \\
\text { ways } \\
\square \quad \text { The teacher guides learners } \\
\text { in gathering, organizing and } \\
\text { evaluating information and ideas } \\
\text { from digital and other resources } \\
\text { and from different perspectives. } \\
\square \quad \text { The teacher structures } \\
\text { interactions among learners and } \\
\text { with local and global peers to } \\
\text { support and deepen learning. }\end{array}$ & 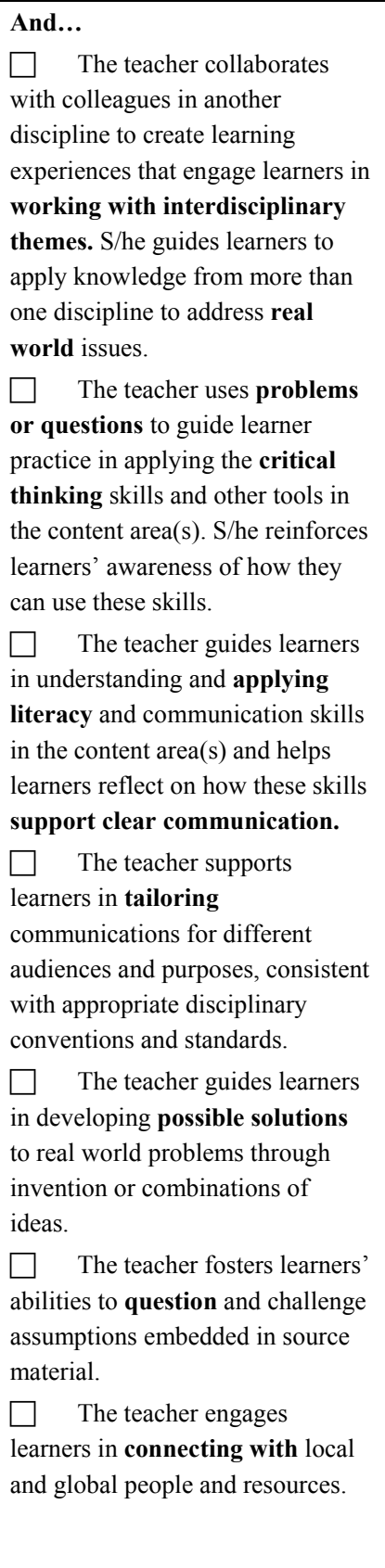 & 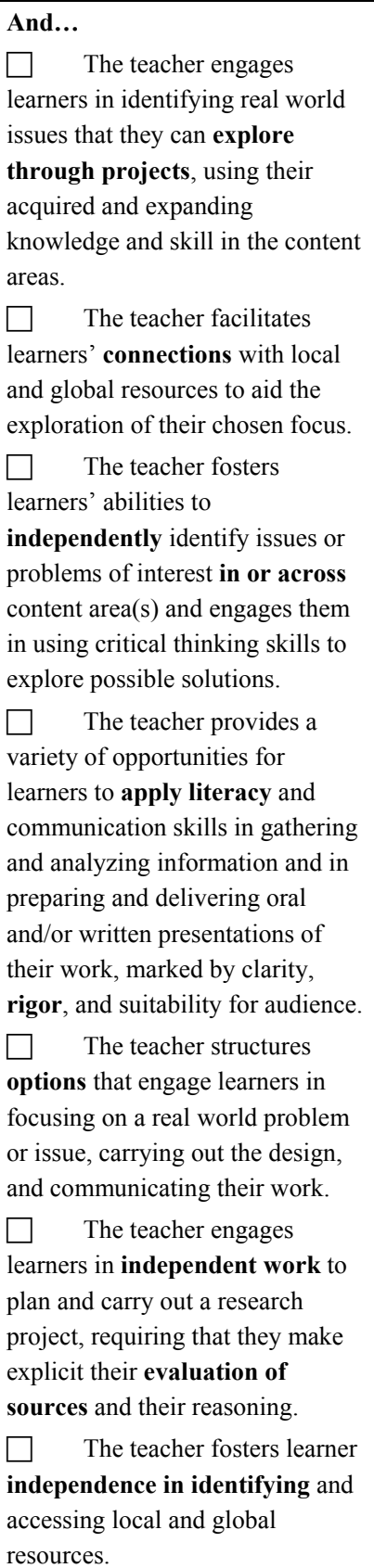 & $\begin{array}{l}\text { Progress } \\
\text { monitoring: } \\
\# \text { of boxes } \\
\text { checked/total \# of } \\
\text { boxes section }\end{array}$ \\
\hline
\end{tabular}

Note. Modified from the InTASC Model Core Teaching Standards and Learning Progressions for Teachers 1.0 (2013, Pages 28-29). 
Standard 6: Assessment

The teacher uses designs or adapts multiple methods of assessment to document, monitor, and support learner progress appropriate for learning objectives. She/he uses assessment to engage learners in their own growth and implements assessments in an ethical manner and minimizes bias to enable learners to display the full extent of their learning.

\begin{tabular}{|c|c|c|c|}
\hline $\begin{array}{l}\text { 1: Essential } \\
\text { Follows ethical codes and uses } \\
\text { multiple assessments for } \\
\text { monitoring progress }\end{array}$ & $\begin{array}{l}\text { 2: Professional } \\
\text { Collaborates with others, uses } \\
\text { effective feedback, and cultivates } \\
\text { prerequisite skills }\end{array}$ & $\begin{array}{l}\text { 3: Exemplary } \\
\text { Collects additional data, teaches } \\
\text { metacognitive skills, and promotes } \\
\text { self-regulation. }\end{array}$ & $\begin{array}{l}\text { Evaluated by: } \\
\text { Preserve teacher } \\
\text { University faculty } \\
\text { School personnel }\end{array}$ \\
\hline $\begin{array}{l}\text { The teacher uses, designs } \\
\text { or adapts a variety of classroom } \\
\text { formative assessments, matching } \\
\text { the method and objective. } \\
\square \quad \text { The teacher uses data from } \\
\text { multiple types of assessments to } \\
\text { draw conclusions about learner } \\
\text { progress toward learning } \\
\text { objectives and uses this analysis } \\
\text { to guide instruction to meet } \\
\text { learner needs. S/he keeps records } \\
\text { to support her/his analysis. } \\
\square \quad \text { The teacher participates in } \\
\text { collegial conversations to } \\
\text { improve instructional practice } \\
\text { based on formative and } \\
\text { summative assessment data. } \\
\square \quad \text { The teacher engages each } \\
\text { learner in examining samples of } \\
\text { quality work. S/he provides } \\
\text { learners with criteria for the } \\
\text { assignment to guide performance. } \\
\text { Using these criteria, s/he points } \\
\text { outs strengths in performance and } \\
\text { offers concrete suggestions for } \\
\text { how to improve their work. } \\
\square \quad \text { The teacher makes digital } \\
\text { and/or other records to monitor } \\
\text { learners' progress. } \\
\square \quad \text { The teacher matches } \\
\text { learning goals with classroom } \\
\text { assessment methods and gives } \\
\text { learners multiple practice } \\
\text { assessments. } \\
\square \quad \text { The teacher engages in } \\
\text { ethical practice of formal and } \\
\text { informal assessment. } \\
\square \quad \text { The teacher implements } \\
\text { required accommodations in } \\
\text { assessments. } \\
\square \quad \text { The teacher differentiates } \\
\text { assessments }\end{array}$ & 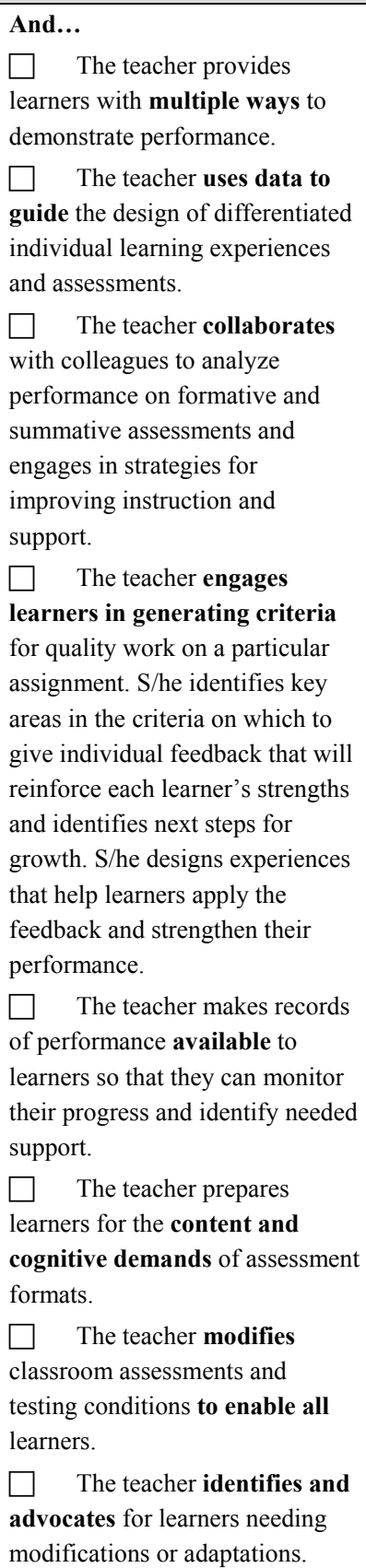 & 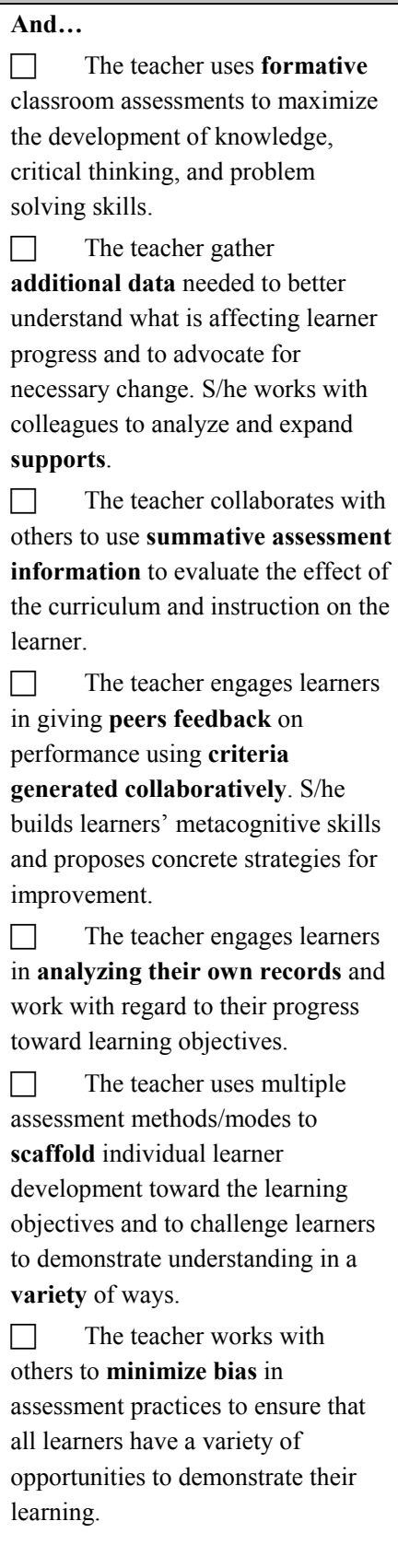 & $\begin{array}{l}\text { Progress } \\
\text { monitoring: } \\
\# \text { of boxes } \\
\text { checked/total \# of } \\
\text { boxes section }\end{array}$ \\
\hline
\end{tabular}

Note. Modified from the InTASC Model Core Teaching Standards and Learning Progressions for Teachers 1.0 (2013, Pages 31-33). 
Standard 7: Planning for Instruction

The teacher selects, creates, and sequences learning experiences and performance tasks that support learners in reaching rigorous curriculum goals based on content standards and cross-disciplinary skills. She/he plans instruction based on information from formative and summative assessments as well as other sources and systematically adjusts plans to meet each student's learning needs. She/he plans instruction by collaborating with colleagues, specialists, community resources, families and learners to meet individual learning needs.

\begin{tabular}{|c|c|c|c|}
\hline $\begin{array}{l}\text { 1: Essential } \\
\text { Develop instruction based on } \\
\text { standards, needs, and assessment }\end{array}$ & $\begin{array}{l}\text { 2: Professional } \\
\text { Teach integrative and life skills } \\
\text { and promote collaboration with } \\
\text { others }\end{array}$ & $\begin{array}{l}\text { 3: Exemplary } \\
\text { Cultivate self-advocacy, } \\
\text { self-monitoring, and } \\
\text { a wide repertoire of skills }\end{array}$ & $\begin{array}{l}\text { Evaluated by: } \\
\text { Preserve teacher } \\
\text { University faculty } \\
\text { School personnel }\end{array}$ \\
\hline $\begin{array}{l}\text { The teacher uses the } \\
\text { provided curriculum materials and } \\
\text { content standards to identify } \\
\text { measurable learning objectives } \\
\text { based on target knowledge and } \\
\text { skills. } \\
\square \quad \text { The teacher plans and } \\
\text { sequences common learning } \\
\text { experiences linked to the learning } \\
\text { objectives, and makes content } \\
\text { relevant to learners. } \\
\square \quad \text { The teacher identifies } \\
\text { learners who need additional } \\
\text { support and/or acceleration and } \\
\text { designs experiences to support. } \\
\square \quad \text { The teacher integrates } \\
\text { technology resources into } \\
\text { instructional plans. } \\
\square \quad \text { The teacher plans } \\
\text { instruction using formative and } \\
\text { summative data, developmental } \\
\text { levels, prior learning, and } \\
\text { interests. } \\
\square \quad \text { The teacher uses data to } \\
\text { identify adjustments. } \\
\square \quad \text { The teacher identifies and } \\
\text { groups learners based on strengths } \\
\text { and/or needs. } \\
\square \quad \text { The teacher uses learner } \\
\text { performance data and her/his } \\
\text { knowledge of learners to support } \\
\text { or advance learning. S/he seeks } \\
\text { assistance from colleagues for } \\
\text { resources. } \\
\square \quad \text { The teacher uses data on } \\
\text { learner performance over time to } \\
\text { inform planning. } \\
\square \quad \text { The teacher uses informal } \\
\text { interactions with families to } \\
\text { adjust plans and to incorporate } \\
\text { home-based resources. }\end{array}$ & 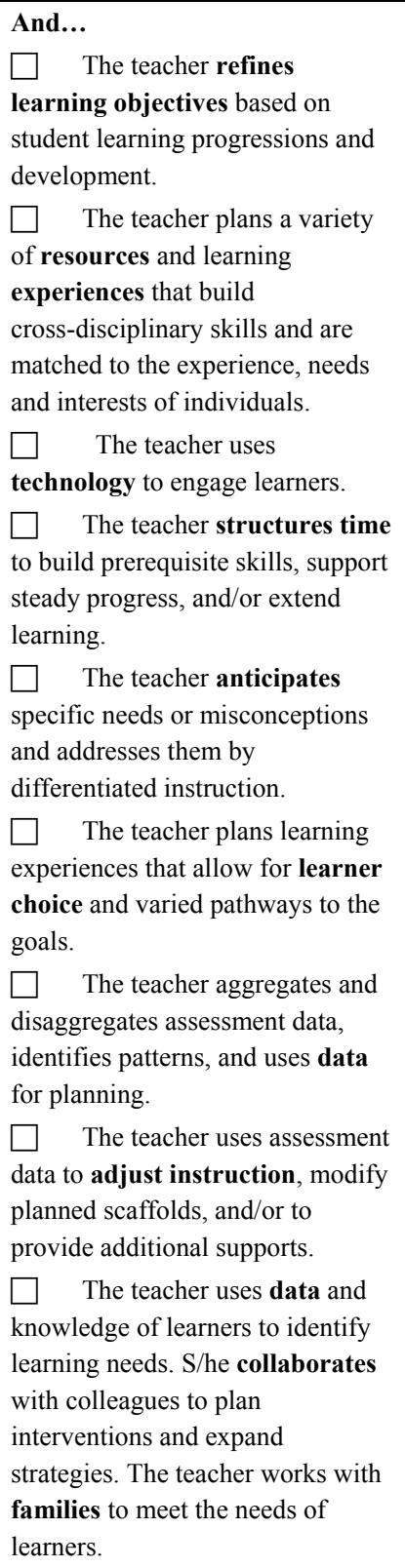 & 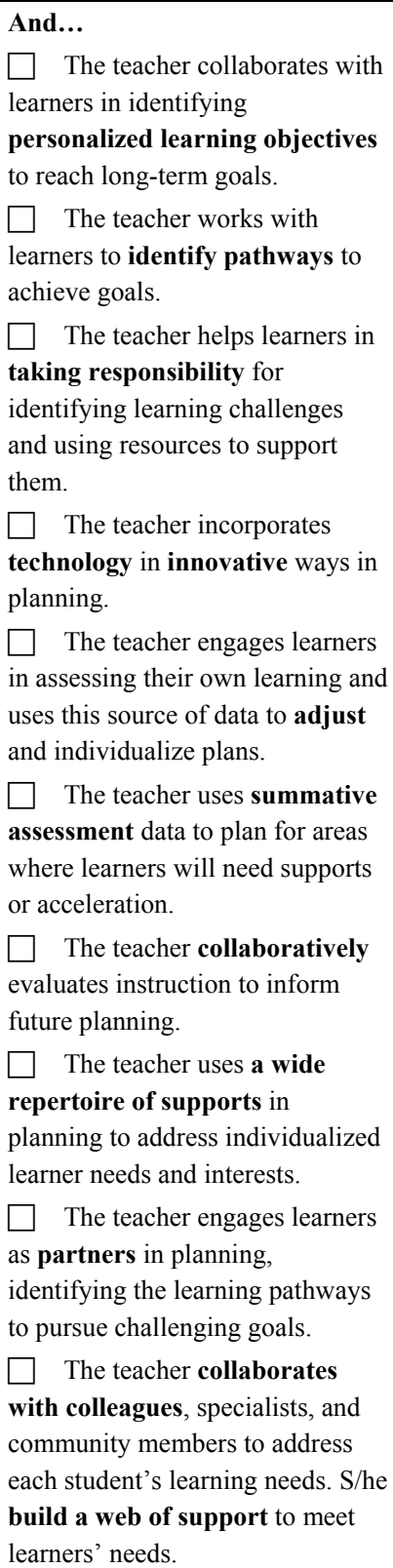 & $\begin{array}{l}\text { Progress } \\
\text { monitoring: } \\
\text { \# of boxes } \\
\text { checked/total \# of } \\
\text { boxes section }\end{array}$ \\
\hline
\end{tabular}

Note. Modified from the InTASC Model Core Teaching Standards and Learning Progressions for Teachers 1.0 (2013, Pages 35-37). 


\section{Standard 8: Instructional Strategies}

The teacher understands and uses a variety of instructional strategies and makes learning accessible to all learners. She/he encourages learners to develop deep understanding of content areas, makes connections across content, and applies content knowledge in meaningful ways.

\begin{tabular}{|c|c|c|c|}
\hline $\begin{array}{l}\text { 1: Essential } \\
\text { Grounds learning goals in standards } \\
\text { and judges source trustworthiness }\end{array}$ & $\begin{array}{l}\text { 2: Professional } \\
\text { Plays different roles in teaching, } \\
\text { offers students choices, and } \\
\text { models concepts }\end{array}$ & $\begin{array}{l}\text { 3: Exemplary } \\
\text { Advocates for learning, promotes } \\
\text { higher-order thinking, and } \\
\text { real-life skills }\end{array}$ & $\begin{array}{l}\text { Evaluated by: } \\
\text { Preserve teacher } \\
\text { University faculty } \\
\text { School personnel }\end{array}$ \\
\hline $\begin{array}{l}\text { The teacher directs learning } \\
\text { experiences through instructional } \\
\text { strategies linked to learning } \\
\text { objectives and content standards. } \\
\square \quad \text { The teacher makes the } \\
\text { learning objective(s) explicit and } \\
\text { understandable to learners, } \\
\text { providing graphic organizers, } \\
\text { models, and representations. } \\
\square \quad \text { The teacher prepares learners } \\
\text { to use specific content-related } \\
\text { processes and academic } \\
\text { language. S/he incorporates } \\
\text { strategies to build group work } \\
\text { skills. } \\
\square \quad \text { The teacher analyzes } \\
\text { individual learner needs as well as } \\
\text { patterns and uses instructional } \\
\text { strategies to respond to those needs. } \\
\square \quad \text { The teacher integrates } \\
\text { primary language resources into } \\
\text { instruction. } \\
\square \quad \text { The teacher seeks assistance } \\
\text { to support language learners. } \\
\square \quad \text { The teacher helps learners } \\
\text { use varied sources access } \\
\text { information. S/he helps students } \\
\text { learn to evaluate the } \\
\text { trustworthiness of sources and } \\
\text { organize information. } \\
\square \quad \text { The teacher poses questions } \\
\text { to elicit learner critical thinking } \\
\text { about information. } \\
\square \quad \text { The teacher models the use } \\
\text { of non-linguistic representations, } \\
\text { concept mapping, and writing. } \\
\square \quad \text { The teacher develops } \\
\text { learners' abilities to participate in } \\
\text { respectful, constructive } \\
\text { discussions of content. }\end{array}$ & 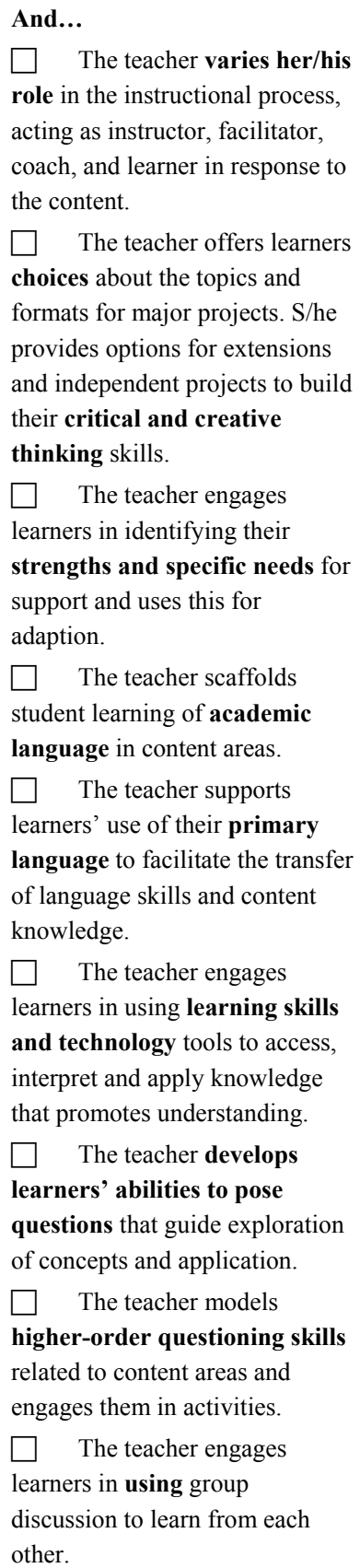 & $\begin{array}{l}\text { And... } \\
\square \quad \text { The teacher serves as an } \\
\text { advocate for learning by } \\
\text { consciously selecting instructional } \\
\text { roles to best meet the needs of } \\
\text { learners. } \\
\square \text { The teacher engages learners } \\
\text { in the design and implementation } \\
\text { of higher order learning } \\
\text { experiences that are aligned with } \\
\text { learning objectives. } \\
\square \text { The teacher scaffolds } \\
\text { learners' ability to identify their } \\
\text { own strengths and needs as } \\
\text { learners and to take responsibility } \\
\text { for setting individual learning } \\
\text { goals, identifying and using } \\
\text { strategies to achieve the goals, } \\
\text { and seeking resources to support } \\
\text { ongoing growth. } \\
\square \quad \text { The teacher engages learners } \\
\text { in recognizing how } \\
\text { accommodations for learning } \\
\text { modes, language proficiency, and } \\
\text { special needs help them to be } \\
\text { successful. } \\
\square \text { The teacher engages learners } \\
\text { in collaborative work to generate, } \\
\text { synthesize, and communicate } \\
\text { information useful to a specific } \\
\text { audience. } \\
\square \text { The teacher collaborates } \\
\text { with learners to create learning } \\
\text { opportunities in which learners } \\
\text { generate questions and design } \\
\text { approaches for addressing } \\
\text { them. } \\
\square \text { The teacher engages learners } \\
\text { in connecting application of } \\
\text { concepts from more than one } \\
\text { content area to real world } \\
\text { problems. }\end{array}$ & $\begin{array}{l}\text { Progress } \\
\text { monitoring: } \\
\text { \# of boxes } \\
\text { checked/total \# of } \\
\text { boxes section }\end{array}$ \\
\hline
\end{tabular}

Note. Modified from the InTASC Model Core Teaching Standards and Learning Progressions for Teachers 1.0 (2013, Pages 39-40). 


\section{Standard 9: Professional Learning and Ethical Practice}

The teacher engages in continuous professional learning to meet the needs of each learner more effectively. She/he uses evidence to evaluate continually the effects of her/his decisions on others and adapts professional practices to better meet learners' needs. Moreover, She/he practices the profession in an ethical manner.

\begin{tabular}{|c|c|c|c|}
\hline $\begin{array}{l}\text { 1: Essential } \\
\text { Follows laws and ethics, conducts } \\
\text { teaching reflection, and continues } \\
\text { to learn }\end{array}$ & $\begin{array}{l}\text { 2: Professional } \\
\text { Takes responsibility for } \\
\text { self-assessment, uses others' } \\
\text { feedback, and helps others }\end{array}$ & $\begin{array}{l}\text { 3: Exemplary } \\
\text { Collaborates with others and assist } \\
\text { others for the betterment of } \\
\text { professional practices }\end{array}$ & $\begin{array}{l}\text { Evaluated by: } \\
\text { Preserve teacher } \\
\text { University faculty } \\
\text { School personnel }\end{array}$ \\
\hline $\begin{array}{l}\text { The teacher engages in } \\
\text { professional learning } \\
\text { opportunities to reflect on, } \\
\text { identify, and address improvement } \\
\text { needs and to enable him/her to } \\
\text { provide learners with engaging } \\
\text { curriculum/experiences. } \\
\square \quad \text { The teacher completes } \\
\text { professional learning processes and } \\
\text { activities required by the state. } \\
\square \quad \text { The teacher actively seeks } \\
\text { professional growth. } \\
\square \quad \text { The teacher observes and } \\
\text { reflects upon learners' responses to } \\
\text { instruction to identify areas and set } \\
\text { goals for improved practice. } \\
\square \quad \text { The teacher seeks and } \\
\text { reflects upon feedback from } \\
\text { colleagues. } \\
\square \quad \text { The teacher gathers, } \\
\text { synthesizes and analyzes a variety } \\
\text { of data to adapt instructional } \\
\text { practices to meet learners' needs. } \\
\square \quad \text { The teacher follows ethical } \\
\text { codes of conduct and professional } \\
\text { standards. } \\
\square \quad \text { The teacher complies with } \\
\text { laws, policies, and rules in their } \\
\text { practices, including learners' rights, } \\
\text { accesses to information and use of } \\
\text { technology. } \\
\square \quad \text { The teacher recognizes how } \\
\text { her/his identity affects perceptions } \\
\text { and biases and reflects on the } \\
\text { fairness and equity of her/his } \\
\text { decisions. } \\
\square \quad \text { The teacher deepens his/ her } \\
\text { understanding of the cultural, } \\
\text { ethnic, gender and learning } \\
\text { differences. } \\
\square \quad \text { The teacher reflects on the } \\
\text { needs of individual learners and } \\
\text { how well they are being } \\
\text { addressed. }\end{array}$ & $\begin{array}{l}\text { And... } \\
\square \quad \text { The teacher takes } \\
\text { responsibility for self-evaluation } \\
\text { of practice and professional } \\
\text { learning. } \\
\square \quad \text { The teacher engages in } \\
\text { professional learning experiences } \\
\text { that broaden her/his } \\
\text { understanding of diverse } \\
\text { learners. } \\
\square \quad \text { The teacher reflects on and } \\
\text { analyzes a wide range of evidence } \\
\text { to evaluate the impact of } \\
\text { instruction and set goals for } \\
\text { improvement. } \\
\square \quad \text { The teacher collaborates } \\
\square \text { with colleagues and others to } \\
\text { give, receive and analyze } \\
\text { feedback on the effects of their } \\
\text { actions. } \\
\square \quad \text { The teacher collaborates } \\
\square \text { with others to gather, synthesize } \\
\text { and analyze data to adapt } \\
\text { planning, practices and other } \\
\text { professional behavior to better } \\
\text { meet individual learner needs. } \\
\square \quad \text { The teacher supports } \\
\text { colleagues in exploring and } \\
\text { making ethical decisions and } \\
\text { adhering to professional } \\
\text { standards. } \\
\square \quad \text { The teacher supports } \\
\text { others in following laws and } \\
\text { policies related to learners' rights } \\
\text { and teachers' responsibilities. } \\
\square \quad \text { The teacher anticipates } \\
\text { information and technology might } \\
\text { be used in unethical or illegal } \\
\text { ways and takes steps to prevent } \\
\text { them. } \\
\square \quad \text { The teacher uses a } \\
\text { deepening understanding of } \\
\text { cultural, ethnic, gender and } \\
\text { learning differences to reflect on } \\
\text { the needs of learners. }\end{array}$ & $\begin{array}{l}\text { And... } \\
\square \quad \text { The teacher collaborates with } \\
\text { colleagues to reflect upon, } \\
\text { analyze, and improve practice to } \\
\text { address learner, school, and } \\
\text { professional needs. } \\
\square \quad \text { The teacher engages and } \\
\text { leads colleagues within the } \\
\text { school/ district/ community in } \\
\text { designing and implementing } \\
\text { professional learning experiences } \\
\text { to improve practice. } \\
\square \quad \text { The teacher leads other } \\
\text { educators in using data to help } \\
\text { evaluate the effects of their actions } \\
\text { and set goals for improvement. } \\
\square \quad \text { The teacher supports and } \\
\text { assists others to extend and refine } \\
\text { their instructional practices and } \\
\text { professional behaviors. } \\
\square \quad \text { The teacher works with } \\
\text { colleagues to deepen the } \\
\text { awareness of the moral and } \\
\text { ethical demands of practices. } \\
\square \quad \text { The teacher collaboratively } \\
\text { evaluates how well laws and } \\
\text { policies serve learners. } \\
\square \quad \text { The teacher advocates for the } \\
\text { safe, legal and ethical use of } \\
\text { information and technology. } \\
\square \quad \text { The teacher assists others in } \\
\text { exploring how personal identity } \\
\text { affect perceptions and assists them } \\
\text { in reflecting upon their biases. } \\
\square \quad \text { The teacher shares } \\
\text { resources and strategies about } \\
\text { cultural, ethnic, gender, and } \\
\text { learning. } \\
\square \quad \text { The teacher advocates for } \\
\text { changes in policy and practice } \\
\text { that better address the needs of } \\
\text { learners. }\end{array}$ & $\begin{array}{l}\text { Progress } \\
\text { monitoring: } \\
\text { \# of boxes } \\
\text { checked/total \# of } \\
\text { boxes section }\end{array}$ \\
\hline
\end{tabular}

Note. Modified from the InTASC Model Core Teaching Standards and Learning Progressions for Teachers 1.0 (2013, Pages 42-44). 
Standard 10: Leadership and Collaboration

The teacher collaborates with learners, families, colleagues, other school professionals, and community members to ensure learner growth. She/he seeks appropriate leadership roles and opportunities to take responsibility for student learning and to advance the profession.

\begin{tabular}{|c|c|c|c|}
\hline $\begin{array}{l}\text { 1: Essential } \\
\text { Develops collaborative } \\
\text { relationships }\end{array}$ & $\begin{array}{l}\text { 2: Professional } \\
\text { Seeks and offers feedback as well as } \\
\text { conducts research }\end{array}$ & $\begin{array}{l}\text { 3: Exemplary } \\
\text { Adopts innovative practice } \\
\text { advocates for others }\end{array}$ & $\begin{array}{l}\text { Evaluated by: } \\
\text { Preserve teacher } \\
\text { University faculty } \\
\text { School personnel }\end{array}$ \\
\hline 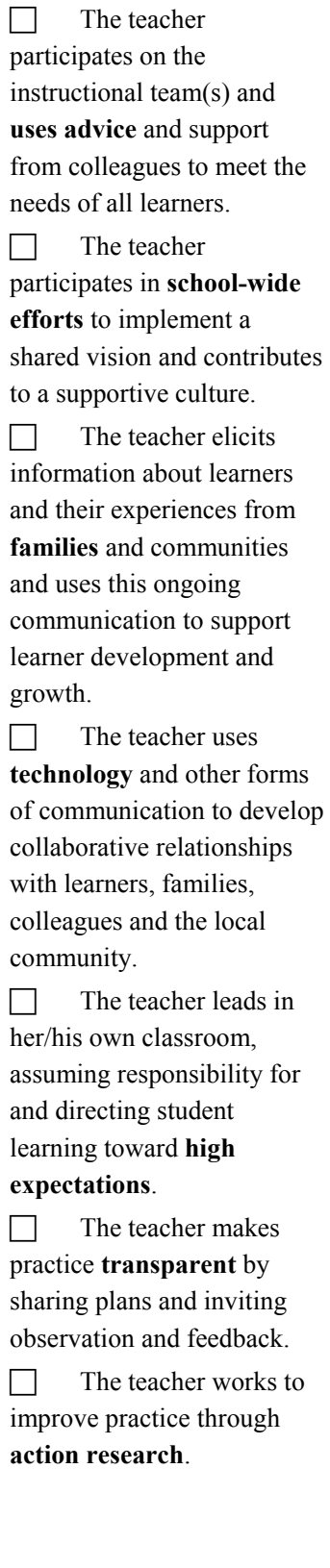 & 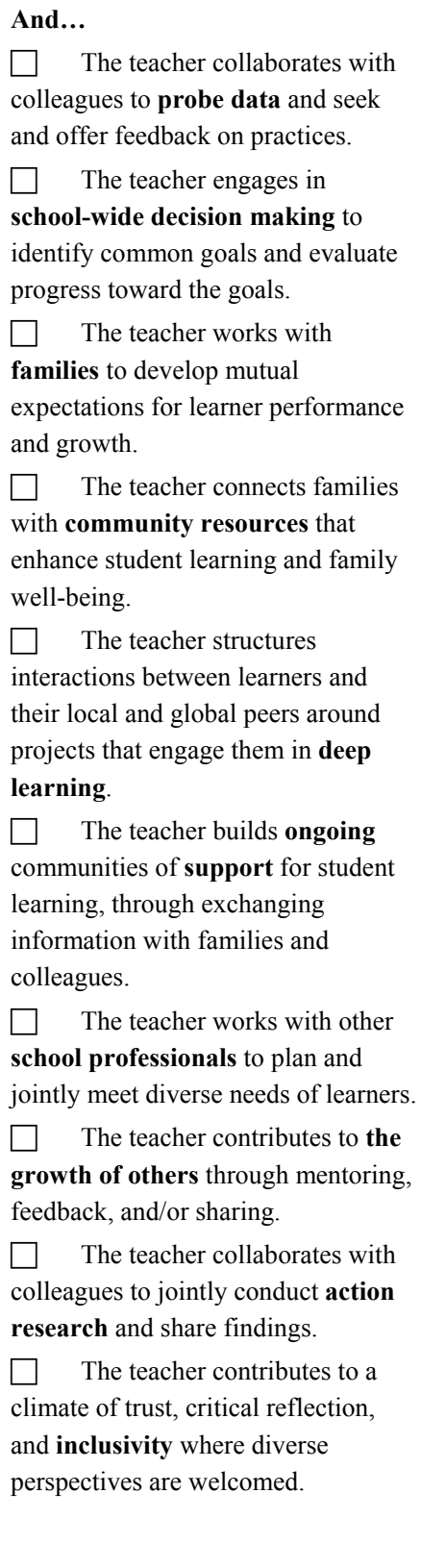 & $\begin{array}{l}\text { And... } \\
\square \quad \text { The teacher brings innovative } \\
\text { practices that meet learning needs } \\
\text { to the instructional team(s) and } \\
\text { supports colleagues. } \\
\square \quad \text { The teacher advocates for } \\
\text { continuous evaluation and } \\
\text { improvement of the school-wide } \\
\text { vision, mission and goals to ensure } \\
\text { alignment with learner needs. } \\
\square \quad \text { The teacher supports } \\
\text { colleagues in developing } \\
\text { communication, and collaboration } \\
\text { with diverse families and } \\
\text { communities. } \\
\square \quad \text { The teacher advocates in the } \\
\text { school and community to meet the } \\
\text { needs of learners and their families. } \\
\square \quad \text { The teacher works } \\
\text { collaboratively across the learning } \\
\text { community of learners, families, } \\
\text { teachers, administrators, and others } \\
\text { to support enhancement of student } \\
\text { learning. } \\
\square \quad \text { The teacher models effective } \\
\text { instructional strategies for } \\
\text { colleagues, leads professional } \\
\text { learning activities, and serves in } \\
\text { other leadership roles. } \\
\square \quad \text { The teacher motivates } \\
\text { colleagues to consider leadership } \\
\text { roles. } \\
\square \quad \text { The teacher works } \\
\text { independently and collaboratively to } \\
\text { generate research and use it as a } \\
\text { way to impact education. } \\
\square \quad \text { The teacher advocates for } \\
\text { learners, the school, the community, } \\
\text { and the profession through } \\
\text { leadership roles at school/ } \\
\text { district/state/nation levels. }\end{array}$ & $\begin{array}{l}\text { Progress } \\
\text { monitoring: } \\
\text { \# of boxes } \\
\text { checked/total \# of } \\
\text { boxes section }\end{array}$ \\
\hline
\end{tabular}

Note. Modified from the InTASC Model Core Teaching Standards and Learning Progressions for Teachers 1.0 (2013, Pages 46-47). 


\section{Copyright Disclaimer}

Copyright for this article is retained by the author(s), with first publication rights granted to the journal.

This is an open-access article distributed under the terms and conditions of the Creative Commons Attribution license (http://creativecommons.org/licenses/by/3.0/). 